\title{
PERSEPSI DOSEN DAN MAHASISWA \\ TERHADAP PEMBELAJARAN APRESIASI SASTRA \\ BERPERSPEKTIF GENDER
}

\author{
NAS HARYATI SETYANINGSIH ${ }^{1}$, MEINA FEBRIANI ${ }^{2}$, ZULIYANTI ${ }^{3}$ \\ Universitas Negeri Semarang \\ nasharyati@mail.unnes.ac.id ${ }^{1}$,meinafebri@mail.unnes.ac.id ${ }^{2}$,zuliyanti@mail.unnes.ac.id²
}

\begin{abstract}
Abstrak
Penelitian ini bertujuan untuk mengungkap persepsi mahasiswa dan dosen terhadap materi, proses, dan penilaian pembelajaran apresiasi sastra.Salah satu mata kuliah yang harus ditempuh oleh mahasiswa Program Studi Pendidikan Bahasa dan Sastra Indonesia adalah mata kuliah Apresiasi Sastra.Membelajarkan apresiasi sastra kepada peserta didik sesungguhnya bukan hal yang mudah karena guru dituntut untuk memastikan agar siswa memiliki pemahaman, penikmatan, dan penilaian terhadap karya sastra. Di sisi lain, dalam membelajarkan sastra, guru perlu memiliki: (1) pemahaman terhadap tujuan pembelajaran sastra, (2) ketepatan memilih, menentukan, dan mengemas materi ajar sastra berdasarkan nilai-nilai atau muatan yang ada di dalamnya, (3) kemampuan memilih dan menggunakan strategi pembelajaran apresiasi sastra yang mampu memantik minat dan pengalaman apresiatif siswa, dan (4) ketepatan dalam memilih dan menggunakan penilaian pembelajaran apresiasi sastra sesuai dengan kompetensi yang diharapkan. Penelitian ini menggunakan pendekatan kualitatif dengan metode deskriptif. Data penelitian ini berupa persepsi mahasiswa dan dosen terhadap pembelajaran apresiasi prosa berperspektif gender. Sumber data penelitian ini adalah mahasiswa peserta kuliah dan dosen mata-mata kuliah apresiasi sastra (Apresiasi Puisi, Apresiasi Prosa, dan Apresiasi Drama) pada Jurusan Pendidikan Bahasa dan Sastra Indonesia, FBS,Universitas Negeri Semarang. Teknik pengumpulan data yang digunakan adalah teknik teknik angket dan wawancara mendalam.Data kuantitatif di dalam penelitian ini dianalisis dengan menggunakan teknik diskriptif persentase. Adapun data yang bersifat kualitatif dianalisis dengan langkah reduksi data,displei data, dan verifikasi data untuk memperoleh simpulan. Hasil penelitian menunjukkan, dosen dan mahasiswa mempersepsi bahwa (1) materi pembelajaran sudah dalam bentuk bahan ajar (hand-out), tetapi belum lengkap karena hanya memuat konsep-konsep yang bersifat teoretis, (2) materi belum memuat nilai-nilai gender, padahal mahasiswa memerlukan nilai tersebut, (2) proses pembelajaran apresiasi sastra menggunakan strategi yang memungkinkan mahasiswa sampai pada tahapan mengapresiasi, akan tetapi metode yang digunakan monoton dan kurang variatif, kegiatan pembelajaran belum sampai pada tahapan akhir apresiasi, yakni mereproduksi, dan proses
\end{abstract}


pembelajaran belum memperhatikan perspektif gender, (3) penilaian pembelajaran apresiasi sastra sudah menggunakan penilaian autentik, namun belum mencakupi keseluruhan aspek penilaian (kognitif, afektif, psikomotor). Penilaian belum memperhatikan perspektif gender.

Kata kunci: pembelajaran apresiasi sastra, perspektif gender

\begin{abstract}
This study aims to reveal the perceptions of students and lecturers on the material, process, and assessment of literary appreciation learning. One of the subjects that must be taken by Indonesian Language and Literature Education Study Program students is the Literature Appreciation course. Learning about literary appreciation to students is not really easy because the teacher is required to ensure that students have an understanding, enjoyment, and assessment of literary work. On the other hand, in teaching literature, the teacher needs to have: (1) understanding of the objectives of literary learning, (2) the accuracy of selecting, determining, and packaging literary teaching material based on the values or content in it, (3) the ability to choose and using literary appreciation learning strategies that are able to ignite students' interest and appreciative experience, and (4) the accuracy in choosing and using assessment of literary appreciation learning in accordance with the expected competencies. This study uses a qualitative approach with descriptive methods. The research data is in the form of perceptions of students and lecturers on gender perspective prose appreciation learning. The data sources of this study are college participants and lecturers of literature appreciation (Poetry Appreciation, Prose Appreciation, and Drama Appreciation) in the Indonesian Language and Literature Education Department, FBS, Semarang State University. Data collection techniques used were questionnaire techniques and in-depth interviews. Quantitative data in this study were analyzed using descriptive percentage techniques. The qualitative data were analyzed by data reduction steps, data dispensing, and data verification to obtain conclusions. The results showed that lecturers and students perceived that (1) learning material was in the form of hand-out material, but it was not complete because it only contained theoretical concepts, (2) the material did not contain gender values, even though students need that value, (2) the literary appreciation learning process uses strategies that allow students to appreciate, but the method used is monotonous and less varied, learning activities have not reached the final stages of appreciation, namely reproducing, and the learning process has not paid attention to perspective gender, (3) assessment of literary appreciation learning has used authentic assessment, but has not covered all aspects of assessment (cognitive, affective, psychomotor). Assessment has not considered a gender perspective.
\end{abstract}

Keywords: literary appreciation learning, gender perspective 


\section{PENDAHULUAN}

Salah satu mata kuliah yang harus ditempuh oleh mahasiswa Program Studi Pendidikan Bahasa dan Sastra Indonesia adalah mata kuliah Apresiasi Sastra. Melalui mata kuliah tersebut, mahasiswa diharapkan memiliki pengetahuan dan keterampilan yang cukup dalam mengapresiasi karya sastra. Kemampuan tersebut merupakan hal penting sebagai bekal mereka setelah lulus dan menjadi guru Mata Pelajaran Bahasa Indonesia di sekolah. Dengan bekal tersebut, diharapkan mereka akan dapat mengajarkan sastra dengan baik.

Agar dapat menjadi sarana pembelajaran dan pembekalan bagi mahasiswa dalam hal kemampuan mengapresiasi sastra, mata kuliah terkait harus memiliki komponen perkuliahan yang memadai. Komponen tersebut di antaranya adalah sumber belajar, metode atau strategi pembelajaran, pengelolaan kelas, keragaman karya sastra sebagai objek kajian, dan penilaian dalam pembelajaran. Keseluruhan hal tersebut merupakan unsur penting yang harus menjadi perhatian dosen pengampu mata kuliah.

Dalam pembelajaran dibutuhkan satu aktivitas yang dapat memicu dan memacu semangat mahasiswa dalam perkuliahan, baik dari segi aktivitas atau proses pembelajaran maupun target akhir yang dituntutkan terhadap mahasiswa. Dalam hal proses misalnya, pengorganisasian aktivitas dalam kelompok yang mengaktifkan mahasiswa perlu dioptimalkan dan dikontrol agar efektif dan tepat sasaran. Sedangkan dalam hal target akhir, mahasiswa perlu diberi tugas atau capaian akhir yang lebih menantang agar mahasiswa lebih memiliki semangat dan tantangan lebih dalam belajar. Dengan demikian, pembelajaran dan penugasan diharapkan dapat memberikan kesempatan seluas-luasnya kepada mahasiswa untuk berpraktik melakukan kegiatan apresiasi karya sastra.

Membelajarkan apresiasi sastra kepada peserta didik sesungguhnya bukan hal yang mudah karena guru dituntut untuk memastikan agar siswa memiliki pemahaman, penikmatan, dan penilaian terhadap karya sastra. Di sisi lain, dalam membelajarkan sastra, guru perlu memiliki: (1) pemahaman terhadap tujuan pembelajaran sastra, (2) ketepatan memilih, menentukan, dan mengemas materi ajar sastra berdasarkan nilai-nilai atau muatan yang ada di dalamnya, (3) kemampuan memilih dan menggunakan strategi pembelajaran apresiasi sastra yang mampu memantik minat dan pengalaman apresiatif siswa, dan (4) ketepatan dalam memilih dan menggunakan penilaian pembelajaran apresiasi sastra sesuai dengan kompetensi yang diharapkan.

Pembelajaran apresiasi sastra diberikan dengan tujuan memiliki implikasi (outcome) atas pembelajaran tersebut. Untuk itu, materi ajar yang digunakan maupun dikembangkan oleh dosen dalam pembelajaran perlu mempertimbangkan aspek isi yang dihubungkan dengan nilai-nilai karakter maupun persoalan-persoalan atau isue-isue yang sedang berkembang dan tengah menjadi sorotan masyarakat. Hal ini penting agar pembelajaran apresiasi sastra bersifat kontekstual dan dan kegunaannya dalam kehidupan dapat dirasakan secara langsung oleh mahasiswa.

Salah satu nilai karakter yang perlu ditanamkan kepada mahasiswa melalui pembelajaran apresiasi sastra adalah nilai kesetaraan dan keadilan gender. Hal tersebut mengingat bahwa meskipun persoalan gender sudah menjadi perhatian pemerintah, di masyarakat masih sering terjadi perisitiwaperistiwa yang menunjukkan adanya ketidakadilan gender.

Pertanyaan yang muncul kemudian adalahapakah pembelajaran apresiasi sastra di LPTK sudah 
dilaksanakan secara optimal? Jika belum, bagaimanakah cara mengoptimalkannya?Berdasarkan latar belakang tersebut, perlu diteliti bagaimana persepsi mahasiswa dan dosen terhadap pembelajaran apresiasi prosa berperspektif gender. Dari penelitian tersebut diharapkan dua permasalahan di atas dapat dijawab.

Secara spesifik, rumusan masalah penelitian ini adalah (1) Bagaimana persepsi mahasiswa dan dosen terhadap materi pembelajaran apresiasi sastra berperspektif gender? (2) Bagaimana persepsi mahasiswa dan dosen terhadap proses pembelajaran apresiasi sastra berperspektif gender? (3) Bagaimana persepsi mahasiwa dan dosen terhadap penilaian pembelajaran apresiasi sastra berperspektif gender? Adapun tujuan penelitian ini adalah (1) mendeskripsikan persepsi mahasiswa dan dosen terhadap materi pembelajaran apresiasi sastra berperspektif gender, (2) mendeskripsikan persepsi mahasiswa dan dosen terhadap proses pembelajaran apresiasi sastra berperspektif gender, dan (3) mendeskripsikan persepsi mahasiwa dan dosen terhadap penilaian pembelajaran apresiasi sastra berperspektif gender.

Secara etimologis, persepsi artinya menerima atau mengambil. Persepsi dalam arti sempit adalah pengelihatan, yaitu bagaimana cara seseorang melihat sesuatu sedangkan dalam arti luas persepsi ialah pandangan atau pengertian, yaitu bagaimana seseorang memandang atau mengartikan sesuatu (Leavitt via Ferlisa 2008:9 dalam Larasati 2016). Pendapat lain menyatakan bahwa persepsi adalah suatu proses untuk mengingat atau mengidentifikasi sesuatu. Atas dasar hal tersebut, persepsi dapat dimaknai sebagai pengalaman dan kesan yang diperoleh seseorang setelah yang bersangkutan melihat atau menghayati serta menginterpretasikan suatu objek.

Persepsi tidak dapat dilepaskan dari harapan.Harapan adalah kecenderungan individu mempersepsi suatu objek sesuai dengan apa yang diinginkan. Ketika seseorang melihat atau menghayati sesuatu maka timbul persepsi dalam diri yang bersangkutan. Apabila yang bersangkutan memiliki keinginan tertentu yang berkaitan dengan objek, akan muncul harapan. Harapan tersebut dapat berupa keinginan untuk terjadinya sesuatu, begitu juga untuk tidak terjadinya sesuatu berkenaan dengan objek yang dimaksud.

Dalam konteks yang lebih luas, apresiasi menurut Gove mengandung makna (1) pengenalan melalui perasaan atau kepekaan batin dan (2) pemahaman dan pengakuan terhadap nilai-nilai keindahan yang diungkapkan pengarang.

Sejalan dengan rumusan pengertian di atas, apresiasi sastra adalah pengenalan dan pemahaman yang tepat terhadap nilai sastra dan kegairahan kepadanya, serta kenikmatan yang timbul sebagai akibat dari semua itu. Atau dengan kata lain, apresiasi sastra adalah adalah kegiatan meggauli karya sastra secara sungguh-sungguh sehingga menumbuhkan pengertian, penghargaan, kepekaan pikiran kritis, dan kepekaan perasaan yang baik terhadap karya sastra (Effendi 1973:18). Dari pendapat itu dapat disimpulkan bahwa apresiasi sastra dapat tumbuh dengan baik apabila pembaca mampu menumbuhkan rasa akrab dengan teks sastra yang diapresiasinya, menumbuhkan sikap sungguhsungguh serta melaksanakan kegiatan apresiasi itu sebagai bagian dari hidupnya, sebagai suatu kebutuhan yang mampu memuaskan rohaniahnya.

Dalam kaitannya dengan pembelajaran, proses apresiasi dibagi menjadi empat tingkatan, yaitu tingkat menggemari, tingkat menikmati, tingkat mereaksi, dan tingkat menghasilkan (Wardani 
1981:1-2). Tingkat menggemari ditandai oleh adanya rasa tertarik terhadap karya sastra serta berkeinginan membaca/menontonnya. Dalam tingkat menikmati, seseorang mulai dapat menikmati karya sastra karena pengertian sudah mulai tumbuh. Tingkat mereaksi ditandai oleh adanya keinginan untuk menyatakan pendapatnya tentang karya yang telah dinikmati. Adapun tingkat menghasilkan ditandai oleh adanya keinginan untuk menghasilkan karya sastra.

Adapun konsep gender mengacu kelompok atribut dan perilaku yang dibentuk secara sosial yang melekat pada kaum laki-laki maupun perempuan yang dikonstruksi secara sosial maupun kultural (Humm 2007:177; Flax dalam Nicholson 1990:45; Fakih 2006:8). Dalam rumusan yang lain, Puspitawati (2012) mendefinisikan gender sebagai perbedaan antara laki-laki dan perempuan dalam peran, fungsi, hak, tanggung jawab, dan perilaku yang dibentuk oleh tata nilai sosial, budaya, dan adat istiadat dari kelompok masyarakat yang dapat berubah menurut waktu serta kondisi setempat. Gender dalam sudut pandang sastra memberikan pemahaman mengenai masalah gender yang tergambar dalam karya sastra. Hal yang sering direpresentasikan dalam karya sastra, terutama prosa, tampak dalam pemilihan tokoh. Jika masalah gender dikaitkan dengan pembelajaran, muncul istilah pembelajaran berperspektif gender. Pembelajaran berperspektif gender adalah sebuah proses pendidikan yang dijiwai oleh kesadaran adanya keadilan dan kesetaraan gender (Wiyatmi 2008:3).

Beberapa penelitian berkenaan dengan persepsi mahasiswa dan dosen tentang pembelajaran sastra dan pembelajaran berperspektif gender telah dilakukan, antara lain Faruk (1997), Sugihastuti (1998), Kaswari (2009), dan Wijayanti dan Dhian (2012).

Pertama, Faruk (1997) menulis tentang perkembangan definisi gender yang berkembang di Indonesia melalui artikel dengan judul "Selayang Pandang Reproduksi Gender di Indonesia". Dalam artikelnya, Faruk (1997) menjelaskan mengenai batasan sudut pandang gender dari segi bahasa dan sastra. Dari sudut pandang bahasa, Faruk (1997) menunjukkan bagaimana bahasa dari segi leksikal, semantik, dan bahkan gramatikal, terbagi atas dasar perbedaan jenis kelamin. Adapun dari sudut pandang sastra, Faruk (1997) menggambarkan dari segi berlawanan. Wanita dalam sastra ditempatkan dalam kerangka hubungan ekuivalensi dengan seperangkat tata nilai marginal dan yang tersubordinatif lainnya, yaitu sentimentalis, perasaan, dan spiritualisme. Kontribusi yang diberikan dari artikel ini antara lain mengenai batasan gender yang akan diaplikasikan dalam mendefinisikan gender dalam pembelajaran sastra di Indonesia.

Kedua, Sugihastuti (1998) meneliti tentang sastra berperspektif feminis yang menekankan pada analisis gender dengan judul "Penelitian Kualitatif Sastra Berperspektif Feminis". Melalui penelitian yang dilakukan, Sugihastuti (1998) menekankan bahwa proses analisis dalam sastra feminis menggunakan analisis gender. Dalam sudut pandang ini, diungkapkan bahwa dalam analisis gender, penelitia harus melibatkan kedua jenis seks manusia dalam mengungkapkan kehidupan tokoh wanita yang dapat dilakukan dengan membandingkan melalui peran, status, dan posisinya. Kontribusi penelitian ini terhadap penelitian yang akan dilakukan adalah mengenai cara penerapan menganalisis gender dalam proses pembelajaran.

Ketiga, Kaswari (2009) menulis artikel mengenai pembelajaran apresiasi prosa fiksi berjudul “Profil Pembelajaran Apresiasi Prosa Fiksi sebagai Kegiatan Rekreatif dan Prokreatif”. Dalam artikel ini, Kaswari (2009) membedakan tingkatan dalam pembelajaran apresiasi prosa menjadi rekreratif 
dan prokreatif. Tingkatan rekreatif ditekankan dalam proses menikmati karya yang dilandasi dengan pemahaman, adapun proses prokreatif ditekankan pada bentuk responsi dan memproduksi karya yang berlandaskan kepekaan emotif, berpikir kritis, dan imajinasi kreatif. Kontribusi yang diberikan terhadap penelitian yang akan dilakukan antara lain mengenai adaptasi langkah yang dapat dilakukan dalam proses rekreatif san prokreatif karya sastra dari sudut pandang pembelajaran apresiasi.

Keempat, Wijayanti dan Dhian (2012) menulis penelitan mengenai kecenderungan pemilihan topik dalam perspektif gender berjudul "Kecenderungan Siswa SMA di Bekasi dalam Memilih Esai Ditinnjau dari Perspektif Gender". Melalui penelitian ini, dekemukakan hasil bahwa siswa perempuan lebih banyak menyukai topik seputar masalah sosial, adapun siswa laki-laki lebih mengyukai masalah teknologi informatika. Melalui penelitian ini dapat diraba mengenai kecanderungan topik dari perspektif gender, hal ini dapat memberikan kontribusi mengenai topik-topik apa yang dapat dijadikan pertimbangan dalam memilih karya pada pembelajaran apresiasi sastra nantinya.

Berdasarkan beberapa penelitian tersebut, dapat disimpulkan bahwa penelitian tentang pembelajaran apresiasi prosa dan perspektif gender dalam pembelajaran telah banyak dilakukan. Meskipun demikian, penelitian tentang persepsi mahasiswa dan dosen terhadap pembelajaran apresiasi prosa berperspektif gender belum dilakukan. Oleh karena itu, diharapkan penelitian ini dapat menjadi pelengkap penelitian yang sudah ada.

\section{METODE PENELITIAN}

\section{Pendekatan Penelitian}

Penelitian ini merupakan penelitian kualitatif. Metode yang digunakan adalah metode deskriptif. Penggunaan metode ini didasarkan pada pertimbangan bahwa penelitian ini mengkaji tentang permasalahan persepsi mahasiswa dan dosen terhadap pembelajaran apresiasi sastra berperspektif gender. Dalam upaya memecahkan masalah penelitian, tahapan yang dilakukan adalah (1) penyediaan data, (2) penganalisisan data, dan (3) penyajian hasil analisis data (Sudaryanto 1993:5).

\section{Data Penelitian}

Data penelitian ini berupa persepsi mahasiswa dan dosen terhadap pembelajaran apresiasi prosa berperspektif gender. Adapun aspek persepsi yang akan digali meliputi: persepsi dosen dan mahasiswa terhadap materi, strategi, metode, teknik, proses, dan penilaian pembelajaran apresiasi sastra berperspektif gender.

\section{Sumber Data}

Sumber data penelitian ini adalah 37 mahasiswa peserta kuliah dan 4 dosen mata-mata kuliah apresiasi sastra (Apresiasi Puisi, Apresiasi Prosa, dan Apresiasi Drama) pada Jurusan Pendidikan Bahasa dan Sastra Indonesia, FBS,Universitas Negeri Semarang.

Responden dipilih secara acak dengan memperhatikan kriteria berikut: (1) untuk mahasiswa: pernah mengikuti pembelajaran apresiasi sastra, sedang aktif mengikuti pembelajaran apresiasi sastra, dan (2) untuk dosen: pernah mengampu mata kuliah apresiasi sastra, sedang aktif mengajarkan apresiasi sastra. 


\section{Teknik Pengumpulan Data}

Pengumpulan data menggunakan teknik kuesioner dan wawancara mendalam.Untuk memenuhi kriteria validitas data digunakan kriteria validitas isi, yaitu pemenuhan aspek validitas dengan menyusun item-item pernyataan yang didasarkan atas masalah dan indikator penelitian yang telah ditemukan melalui pengamatan sebelumnya sehingga pernyataan-pernyataan dalam angket sesuai dengan substansi masalah yang diteliti. Adapun data dari dosen diambil melalui wawancara langsung.

Data kuantitatif dianalisis dengan menggunakan teknik diskriptif persentase. Adapun data yang bersifat kualitatif dianalisis dengan langkah reduksi data,displei data, dan verifikasi data untuk memperoleh simpulan.

\section{HASIL PENELITIAN DAN PEMBAHASAN}

\section{Hasil Penelitian}

\section{Persepsi Dosen terhadap Pembelajaran Apresiasi Sastra Berperspektif Gender}

Persepsi dosen terhadap materi pembelajaran apresiasi sastra dijaring melalui kegiatan wawancara mendalam. Dari hasil wawancara diketahui bahwa dosen mengembangkan materi pembelajaran berdasarkan silabus dan RPS. Materi pembelajaran yang dikemas dalam bahan ajar yang wajib dimiliki mahasiswa. Akan tetapi materi yang dikembangkan masih terbatas pada konsep teoretis. Contoh-contoh praktik apresiasi kurang mendapat perhatian. Materi ajar yang digunakan masih terbatas pada beberapa buku referensi dan kurang bervariasi. Sebagian besar (75\%) dosen menyatakan belum mengintegrasikan nilai-nilai perspektif gender dalam materi pembelajaran yang diperlukan untuk menumbuhkan rasa kesetaraan dan keadilan di antara mahasiswa. Kondisi tersebut diketahui dari minimnya karya sastrayang digunakan dalam pembelajaran apresiasi sastra dan tidak terdapat muatan perspektif gender di dalamnya.

Materi pembelajaran hendaknya disediakan secara lengkap dan bervariasi dari berbagai sumber belajar. Sumber belajar dapat disediakan di perpustakaan secara lengkap dan beragam. Namun, berdasarkan hasil wawancara diketahui bahwa ketersediaan sumber belajar, seperti buku referensi dan karya sastra.Materi ajar yang berperspektif gender dalam pembelajaran apresiasi sastra masih sangat terbatas. Ketersediaan buku ajar atau referensi dan karya sastra yang berperspektif gender di perpustakaan juga masih minim.

Pembelajaran apresiasi sastra belum terlaksana secara maksimal. Berdasarkan hasil wawancara mendalam diketahui bahwa pembelajaran dilaksanakan dengan strategi pembelajaran yang konvensional. Metode pembelajaran yang sering digunakan oleh dosen adalah metode ceramah, tanya jawab, penugasan, dan diskusi. Proses pembelajaran diawali dengan kontrak perkuliahan, penyampaian konsep dan teori, tugas membuat makalah, dan presentasi makalah. Penggunaan strategi pembelajaran tersebut berdampak pada kurangnya semangat mahasiswa selama pembelajaran berlangsung, hasil pembelajaran kurang maksimal, dan minimnya pemahaman mahasiswa tentang perspektif gender.

Berdasarkan hasil wawancara diketahui bahwa dosen belum pernah menggunakan model 
pembelajaran yang mengintegrasikan nilai-nilai perspektif gender. Kegiatan mengapresiasi karya sastra masih terbatas pada karya sastra yang belum bermuatan perspektif gender. Selain itu, kegiatan pembelajaran hanya berakhir pada kegiatan meresepsi dan belum memberikan kesempatan kepada mahasiswa untuk berkreasi dengan cara mereproduksi hasil apresiasi terhadap karya sastra yang dibaca, padahal mahasiswa berpotensi mengembangkan kemampuannya dalam memproduksi karya sastra baru dari hasil resepsinya.

Media pembelajaran merupakan penunjang pembelajaran yang dapat mempermudah penyampaian materi pembelajaran. Media pembelajaran dibutuhkan dalam pembelajaran apresiasi sastra agar dapat membantu mahasiswa dalam memahami materi ajar dan mampu mengapresiasi karya sastra yang dibaca sehingga dapatmenerapkan nilai-nilai yang terkandung di dalamnya dalamkehidupan sehari-hari. Namun pada kenyataannya, penggunaan media pembelajaran dalam pembelajaran apresiasi sastra masih terbatas. Dosen lebih sering menggunakan media pembelajaranpower point sehingga terkesan kurang kreatif dan variatif. Selain itu, media pembelajaran yang digunakan masih belum bermuatan nilai-nilai perspektif gender.

Dalam pembelajaran apresiasi sastra dibutuhkan suasana pembelajaran yang menyenangkan dan menarik agar dapat mendukung perkembangan kemampuan dan kreativitas mahasiswa. Suasana pembelajaran dapat dibangun dengan memanfaatkan lingkungan kampus secara maksimal, seperti panggung terbuka, gasebo, taman kampus, lapangan, dan ruang laboratorium. Pemanfaatan tempat belajar baru dapat menumbuhkan semangat belajar dan mendukung kreativitas mahasiswa dalam mengapresiasi karya sastra dan menerapkan nilai-nilai kehidupan dalam karya sastra tersebut dalam kehidupan sehari-hari. Hal tersebut terungkap melalui wawancara dengan dosen pengampu.

Melalui wawancara dengan dosen terungkap bahwa penilaian pembelajaran apresiasi sastra dilaksanakan dalam bentuk penugasan. Dalam hal ini mahasiswa diberi tugas untuk menganalisis karya sastra dengan menggunakan pendekatan/metode tertentu kemudian memaparkan hasil analisisnya dalam bentuk makalah. Dari 4 dosen yang dijadikan responden, hanya satu orang yang menyatakan bahwa konsep teoretis juga diujikan.

\section{Persepsi Mahasiswa terhadap Pembelajaran Apresiasi Sastra Berperspektif Gender}

'Persepsi mahasiswa terhadap pembelajaran apresiasi sastra berperspektif gender dijaring melalui pengisian lembar kuesioner. Aspek yang dijaring dalam kuesioner tersebut meliputi tujuan/ kompetensi pembelajaran apresiasi sastra, materi ajar pembelajaran apresiasi sastra berperspektif gender, dan model pembelajaran apresiasi sastra berperspektif gender, dan penilaian pembelajaran. Berperspektif gender.

Aspek tujuan/kompetensi pembelajaran apresiasi sastra dikaitkan dengan kompetensi pembelajaran yang harus dicapai mahasiswa meliputi aspek kognitif, afektif, dan psikomotorik. Pernyataan tersebut diketahui bahwa ada 18 (49\%) mahasiswa menyatakan sangat setuju dan 15 (41\%) mahasiswa menyatakan setuju. Mahasiswa menyatakan bahwa capaian pembelajaran apresiasi sastra memuat nilai-nilai kesetaraan dan keadilan gender sebanyak 8 (22\%) orang sangat setuju, 25 $(68 \%)$ orang setuju, dan 5 (14\%) orang kurang setuju. Tahapan pembelajaran apresiasi sastra adalah memahami, menikmati, mereaksi, menilai, dan menghasilkan. Hasil pengisian kuesioner diketahui bahwa mahasiswa yang menyatakan sangat setuju sebanyak 21 (57\%) orang, setuju 15 (41\%) orang, 
dan kurang setuju 1 (3\%) orang. Selanjutnya, pernyataan bahwa tujuan pembelajaran apresiasi sastra di Program Studi Pendidikan Bahasa dan Sastra Indonesia harus sampai pada tahapan terakhir apresiasi, yaitu mengungkapkan hasil apresiasinya dalam bentuk tertentu (reproduksi) diketahui bahwa ada 13 (35\%) mahasiswa menyatakan sangat setuju, 20 (54\%) mahasiswa setuju, dan 4 (11\%) mahasiswa kurang setuju.

Aspek materi pembelajaran apresiasi sastra berperspektif gender dijaring dengan beberapa indikator, yaitu perasaan mahasiswa selama pembelajaran, kebutuhan mahasiswa akan fasilitator selama pembelajaran berlangsung dan ketersediaan materi ajar serta sumber belajar yang disiapkan oleh dosen dan pihak kampus. Perasaan mahasiswa selama pembelajaran dikaitkan dengan perasaan tidak nyaman mahasiswa ketika berhubungan dengan teman yang berbeda jenis kelamin yang diketahui bahwa 8 (22\%) mahasiswa menyatakan setuju, 19 (51\%) mahasiswa kurang setuju, dan 13 (35\%) mahasiswa tidak setuju. Mahasiswamerasa tidak nyaman ketika berada di lingkungan yang sebagian besar berbeda jenis kelamin diketahui sebanyak $4(11 \%)$ orang menyatakan sangat setuju, $11(30 \%)$ orang setuju, $17(46 \%)$ orang kurang setuju, dan $5(14 \%)$ orang tidak setuju. Pernyataan mahasiswa jika lebih senang berkelompok dengan teman yang berjenis kelamin sama diketahui ada 4 (11\%) orang setuju, 21 (57\%) orang kurang setuju, dan 11 (30\%) orang tidak setuju.

Dalam pembelajaran apresiasi sastra dibutuhkan pengembangan materi ajar dengan mengintegrasikan nilai-nilai perspektif gender di dalamnya. Berdasarkan hasil pengisian kuesioner diketahui bahwa mahasiswa yang menyatakan sangat setuju sebanyak 2 (5\%) orang, setuju 17 (46\%) orang, kurang setuju 15 (41\%) orang, dan tidak setuju sebanyak 3 (8\%) orang. Ketersedian sumber pustaka dan karya sastra yang berperspektif gender di perpustakaan masih kurang. Pernyataan tersebut diketahui dari pernyataan mahasiswa yang sangat setuju sebanyak $3(8 \%)$ orang, setuju sebanyak 27 (73\%), kurang setuju sebanyak 5 (14\%), dan tidak setuju sebanyak 1 (3\%) orang. Dalam pembelajaran apresiasi sastra dibutuhkan penerapan model pembelajaran yang menarik, menyenangkan, dan variatif. Hal tersebut diketahui dari hasil pengisian kuesioner bahwa mahasiswa menyatakan sangat setuju sebanyak 19 (51\%) orang, setuju sebanyak 14 (38\%) orang, dan kurang setuju sebanyak 4 (11\%) orang.

Selama ini, pembelajaran apresiasi sastra masih didominasi dengan penerapan metode pembelajaran yang konvensional, seperti: metode ceramah, diskusi, tanya jawab, dan penugasan. Pernyataan tersebut dibenarkan dengan adanya pernyataan mahasiswa sangat setuju sebanyak 5 (14\%) orang, setuju sebanyak 17 (46\%) orang, dan kurang setuju sebanyak 5 (14\%) orang. Dalam persepsi mahasiswa, pengintegrasian nilai-nilai perspektif gender belum tampak dalam proses pembelajaran apresiasi sastra. Hal tersebut diketahui dari minimnya kesempatan yang diberikan kepada mahasiswa untuk membaca, memahami, dan menerapkan nilai-nilai perspektif gender dalam pembelajaran apresiasi sastra. Pernyataan tersebut didukung dengan hasil pengisian kuesioner bahwa mahasiswa yang menyatakan sangat setuju sebanyak 11 (30\%) orang, setuju sebanyak 25 (68\%), dan kurang setuju sebanyak $1(3 \%)$ orang.

Penilaian pembelajaran apresiasi sastra dilaksanakan dengan menggunakan teknik tes dan unjuk kerja (mengapresiasi karya sastra). Hal tersebut didukung oleh hasil kuesioner mahasiswa yang menyatakan sangat setuju sebanyak 19 (51\%) orang, setuju sebanyak $14(38 \%)$ orang, dan kurang setuju sebanyak 4 (11\%) orang. Penilaian pembelajaran juga mengutamakan pengembangan kemampuan 
berpikir dan mengimajinasikan permasalahan yang diusung dalam karya sastra. Pernyataan tersebut didukung oleh hasil pengisian kuesioner yang menyatakan sangat setuju sebanyak 5 (14\%) orang, setuju sebanyak 17 (46\%) orang, dan kurang setuju sebanyak 5 (14\%) orang. Akan tetapi, belum ada balikan dari dosen terhadap hasil penilaian. Hal tersebut didukung oleh hasil kuesioner mahasiswa yang menyatakan sangat setuju sebanyak 19 orang (51\%), setuju sebanyak 14 orang (38\%), dan tidak setuju sebanyak 4 orang (11\%).

\section{Pembahasan}

Dari hasil wawancara dengan dosen dan kuesioner mahasiswa terungkap bahwa dosen sudah menyediakan materi pembelajaran dalam bentuk bahan ajar (hand-out). Meskipun demikian, bahan ajar tersebut belum lengkap karena hanya memuat konsep-konsep yang bersifat teoretis. Padahal, tujuan akhir pembelajaran apresiasi sastra adalah agar mahasiswa memiliki kompetensi berapresiasi sastra yang baik. Artinya, materi yang dibutuhkan bukan hanya berupa konsep teoretis, melainkan juga contoh-contoh hasil apresiasi/kajian.

Dari hasil wawancara dan kuesioner juga terungkap bahwa isi materi pembelajaran dan karya sastra yang diapresiasi belum bermuatan perspektif gender. Padahal, menurut persepsi mahasiswa, nilai-nilai perspektif gender dalam materi pembelajaran apresiasi sastra menjadi hal yang penting untuk mengenalkan dan memberikan pemahaman tentang konsep perspektif gender kepada mahasiswa. Peristiwa gender yang muncul dalam karya sastra dapat dijadikan contoh dan bahan kajian mahasiswa untuk dianalisis faktor-faktor penyebab dan penyelesaian atas permasalahan tersebut. Proses tersebut dapat melatih mahasiswa untuk dapat berpikir kritis dan bertanggung jawab dalam menyelesaikan berbagai permasalahan yang berkaitan dengan gender. Peristiwa tersebut juga dapat menjadi stimulus bagi mahasiswa untuk mengonstruksi konsep gender dengan cara mengaitkan peristiwa gender dalam karya sastra dengan peristiwa yang pernah dialami oleh mahasiswa. Proses mengidentifikasi dan menganalisis peristiwa gender dalam karya sastra melatih mahasiswa untuk dapat berpikir kritis dan bertanggung jawab. Berdasarkan pentingnya muatan perspektif gender bagi pembentukan karakter mahasiswa, seharusnya nilai-nilai gender diintegrasikan dalam materi pembelajaran apresiasi sastra.

Berkaitan dengan aspek ketersediaan sumber belajar, baik dosen maupun mahasiswa setuju bahwa sumber belajar merupakan hal penting dan harus tersedia untuk mendukung kelangsungan belajar mahasiswa. Mahasiswa dapat memeroleh ilmu secara mendalam dengan membaca berbagai buku referensi dan karya sastra dari berbagai pengarang. Berdasarkan hasil wawancara dan kuesioner diketahui bahwa buku-buku referensi dan karya sastra, termasuk yang berperspektif gender,sudah ada tetapi jumlahnya belum memadai. Padahal, ketersediaan buku referensi di perpustakaan sangat membantu mahasiswa untuk memahami materi pembelajaran.Karya sastra berperspektif gender yang diapresiasi dalam pembelajaran apresiasi sastra pun masih terbatas jumlahnya. Dengan mengacu padahal tersebut, sumber belajar yang bermuatan perspektif gender perlu disediakan secara maksimal dalam rangka mendukung proses dan hasil pembelajaran apresiasi sastra.

Dalampemilihanstrategi,metode, dan teknikpembelajaran terungkapbahwametodeyangumum digunakan dosen adalah metode ceramah dan pemberian tugas yang dalam pelaksanaannya melalui kegiatan pemberian konsep teoretis, tugas menganalisis, membuat makalah, dan mempresentasikan makalah. Hal tersebut membuat pembelajaran kurang menarik dan kurang variatif. Pembelajaran 
yang monoton dapat menjadikan mahasiswa cepat bosan dan tidak dapat berkonsentrasi selama belajar. Suasana hati yang demikian memberi pengaruh besar terhadap perasaan kurang nyaman dan tidak senang sehingga mahasiswa tidak dapat belajar dengan baik. Hal tersebut juga terungkap dari hasil kuesioner mahasiswa yang menyatakan bahwa dalam pembelajaran apresiasi sastra dibutuhkan suasana belajar yang menarik, menyenangkan, tidak membosankan, dan mendukung kreativitas mahasiswa agar lebih produktif. Suasana belajar yang menyenangkan akan berdampak pada proses belajar yang kondusif dan hasil belajar yang maksimal. Mahasiswa membutuhkan motivasi belajar dan suasana belajar yang mendukung kerja sama dan saling menghormati antarmahasiswa baik laki-laki maupun perempuan. Interaksi mahasiswa satu dengan mahasiswa yang lain, terutama yang berbeda jenis kelamin, perlu dikondisikan agar berlangsung dalam suasana nyaman dan berkeadilan gender. Mahasiswa memerlukan dukungan agar dapat berinteraksi dengan baik dengan lawan jenis. Dengan demikian, dalam pembelajaran apresiasi prosa dibutuhkan suasana pembelajaran yang menyenangkan dan kondusif yang dapat mendukung mahasiswa dalam berinteraksi dengan mahasiswa lain tanpa membedakan gender.

Media pembelajaran merupakan sarana yang memudahkan mahasiswa dalam memahamai materi pembelajaran. Dalam pembelajaran apresiasi sastra diperlukan media pembelajaran yang tepat agar mahasiswa dapat memahami materi secara maksimal. Dalam proses mengapresiasi karya sastra diperlukan media pembelajaran yang dapat memudahkan mahasiswa dalam mengidentifikasi, memahami, menilai, meresepsi, dan memproduksi karya baru yang berperspektif gender dari hasil apresiasinya. Selain itu, dibutuhkan juga media pembelajaran yang efektif agar dapat membantu mahasiswa dalam memahami perspektif gender dengan baik. Dari hasil wawancara dan kuesioner diketahui bahwa doesn sudah menggunakan media pembelajaran, akan tetapi masih kurang variatif. Oleh karena itu, diperlukan media yang lebih menarik dan variatif agar memermudah mahasiswa dalam memahami materi dengan baik sehingga diperoleh hasil belajar yang maksimal.

Nilai-nilai perspektif gender adalah nilai yang perlu ditanamkan kepada mahasiswa sebagai bekal hidup bermasyarakat. Selama ini, mahasiswa sering dihadapkan pada permasalahan gender. Untuk menemukan solusi atas permasalahan tersebut diperlukan pemahaman yang baik tentang gender. Berdasarkan hasil wawancara diketahui bahwa mahasiswa kurang memahami konsep gender. Oleh sebab itu diperlukan pemahaman terhadap konsep gender dan contoh-contoh peristiwa berperspektif gender. Kesempatan belajar tentang konsep gender dibangun dengan cara memberikan kesempatan kepada mahasiswa untuk menemukan sendiri berbagai permasalahan yang muncul dalam karya yang diapresiasi. Dari hasil identifikasi tersebut, mahasiswa diharapkan mampu mengonstruksi definisi gender dengan baik yang kemudian diaplikasikan dengan cara penyelesaian masalah gender dalam kehidupan sehari-hari. Mahasiswa juga membutuhkan perlakuan yang sama antara laki-laki dan perempuan dalam pembelajaran apresiasi prosa dengan pemberian kesempatan berpendapat, berkelompok, dan berkreasi secara adil dan merata. Selama ini, di dalam proses pembelajaran apresiasi prosa belum memperhatikan masalah gender. Oleh karena itu, diperlukan perlakuan yang sama antara mahasiswa laki-laki dan perempuan dalam pembelajaran apresiasi prosa untuk menghindari munculnya permasalahan gender.

Terkait dengan penilaian pembelajaran apresiasi sastra terungkap bahwa dosen sudah melaksanakan penilaian autentik, yakni menugasi mahasiswa untuk mengapresiasi karya sastra 
yang dibaca, kemudian menuangkan hasil apresiasinya dalam bentuk makalah sebahai tugas akhir perkualiahan. Meskipun demikian, penilaian belum mencakupi keseluruhan aspek (kognitif, afektif, psikomotor). Padahal, seharusnya penilaian hasil belajar mencakupi ketiga aspek tersebut.

\section{PENUTUP}

Berdasarkan hasil penelitian dan pembahasan disimpulkan bahwa (1) Dosen dan mahasiswa mempersepsi bahwa materi pembelajaran sudah dalam bentuk bahan ajar (hand-out), tetapi belum lengkap karena hanya memuat konsep-konsep yang bersifat teoretis. Materi belum memuat nilainilai gender, padahal mahasiswa memerlukan nilai tersebut, (2) dosen dan mahasiswa mempersepsi bahwa proses pembelajaran apresiasi sastra menggunakan strategi yang memungkinkan mahasiswa sampai pada tahapan mengapresiasi, akan tetapi metode yang digunakan monoton dan kurang variatif. Kegiatan pembelajaran belum sampai pada tahapan akhir apresiasi, yakni mereproduksi. Proses pembelajaran belum memperhatikan perspektif gender, dan (3) dosen dan mahasiswa mempersepsi bahwa penilaian pembelajaran apresiasi sastra sudah menggunakan penilaian autentik, namun belum mencakupi keseluruhan aspek penilaian (kognitif, afektif, psikomotor). Penilaian belum memperhatikan perspektif gender.

Saran

Bedasarkan hasil penelitian disarankan agar (1) dikembangkan materi pembelajaran yang memuat konsep teoretis dan contoh-contoh hasil kajian dengan mengintegrasikan perspektif gender, (2) dikembangkan strategi, metode, teknik, atau model pembelajaran yang menyenangkan dan memungkinkan mahasiswa mengapresiasi karya sastra berperspektif gender sampai pada tahap akhir apresiasi, yakni mereproduksi, dan (3) perlu dikembangkan penilaian pembelajaran apresiasi sastra berperspektif gender yang mencakupi aspek kognitif, afektif, dan psikomotorik.

\section{DAFTAR PUSTAKA}

Faruk. 1997. "Selayang Pandang Reproduksi Gender di Indonesia” dalam Jurnal Humaniora Nomor 6. Universitas Gadjah Mada.

Kaswari. 2009. "Profil Pembelajaran Apresiasi Prosa Fiksi sebagai Kegiatan Rekreatif dan Prokreatif" dalam JurnalCakrawala Pendidikan vol.7 no.2. Universitas Negeri Yogyakarta.

Keputusan Menteri Pendidikan dan Kebudayaan Nomor 045/u/2002 tentang Kurikulum Inti.

Larasati, Gilang. 2016. "Pengaruh Persepsi Tentang Pembelajaran Sastra Terhadap Kemampuan Apresiasi Sastra Siswa Kelas Xi Smk Negeri Se-Kabupaten Kebumen”.thesis, Universitas Negeri Yogyakarta. 
Luxemburg, Jan van, Mieke Bal, dan Willem G. Weststeijn. 1989. Pengantar Ilmu Sastra. Terjemahan Dick Hartoko. Jakarta: Gramedia.

Mulyatiningsih, Endang, Amat Jaedun, Heri Retnawati. 2012." Profil Kemampuan Penguasaan Materi Pelajaran Guru SMA Di DI Yogyakarta dan Jawa Tengah” Laporan Penelitian. http://eprints. uny.ac.id/24552/8. Diunduh 5 April 2017.

Peraturan Pemerintah Nomor 16 Tahun 2007 tentang StandarKualifikasi Akademik dan Kompetensi Guru.

Peraturan Pemerintah Nomor 19 Tahun 2015 tentang Standar Nasional Pendidikan.

Pusat Statistik. 2016. Analisis Gambaran Kompetensi Guru terhadap Prestasi Belajar Siswa SMP pada Ujian Nasional Tahun 2015 di Provinsi Daerah Istimewa Yogyakarta. Jakarta: Departemen Pendidikan dan Kebudayaan.

Rozak, Abdul. 2013. "Profil Calon Guru Sastra; Studi pada Mahasiswa Program Studi Pendidikan Bahasa dan Sastra Indonesia, FKIP-Unswagati Cirebon”. Disampaikan pada Seminar Nasional Asosiasi Pengajar Bahasa Indonesia, Bogor 27-28 November 2013.

Saadiah. 2013.Tingkat Penguasaan Materi Kecepatan Membaca Guru SMA se-Kabupaten Aceh Besar. Metamorfosa Volume 1 Nomor 1 Janiari-Juni, halaman 49-63.

Sudaryanto. 1993. Metode dan Aneka Teknik Analisis Bahasa: Pengantar Penelitian Wahana Kebudayaan secara Linguistis. Yogyakarta: Duta Wacana University Press.

Sugihastuti. 1998. "Penelitian Kualitatif Sastra Berperspektif Feminis" dalam Jurnal Humaniora no.8. Universitas Gadjah Mada.

Sugihastuti. 2007. Teori dan Apresiasi Sastra. Yogyakarta: Pustaka Pelajar.

Sumardjo, Jacob \& Saini K.M. Apresiasi Kesusasteraan. Jakarta: Gramedia\

Undang-Undang Nomor 14 tahun 2005 tentang Guru dan Dosen. 
Wijayanti, Sri Hapsari, dan Claudia Dhian. 2012. "Kecenderungan Siswa di Bekasi dalam Memilih Topik Esai Ditinjau dari Perrspektif Gender" dalam Jurnal Humaniora vol 24 no.2. Universitas Gadjah Mada. 